\title{
Microbiological quality of meals served in nursing homes in the city of Ponta Grossa, Paraná
}

\author{
Luciana de ALMEIDA ${ }^{1 *}$, Denise Milleo de ALMEIDA², Giovana de Arruda Moura PIETROWSKI²
}

\begin{abstract}
The aim of this study was to analyze the microbiological quality of meals served in nursing homes in the city of Ponta Grossa, Paraná, before and after the training of food handlers. The first stage was to perform a checklist conforming with current legislation. The second consisted of the collection of 4 food samples from each location and a microbiological investigation in accordance with the relevant legislation. The third was the training of food handlers in relation to good food handling practices. The fourth was a further microbiological analysis of new samples. The application of a checklist showed that the locations met the requirements of current legislation. Of the 40 samples analyzed, $17.5 \%$ ( 7 samples) were unfit for consumption. Among the unfit samples $15 \%$ ( 6 samples) had coliforms at $45^{\circ} \mathrm{C}$, 2.5\% ( 1 sample) had coagulase-positive staphylococci, $2.5 \%$ ( 1 sample) had Bacillus cereus and 2.5\% (1 sample) had Salmonella sp. The results of this study show the importance of controlling the quality of food served to an age group that is prone to health risks.
\end{abstract}

Keywords: elderly; microbiological analyses; contamination; training; food handlers.

Practical Application: The importance of good manufacturing practices and dissemination of knowledge to the community.

\section{Introduction}

The number of elderly people in Brazil is growing rapidly and this population frequently suffers from chronic diseases. Food insecurity and nutritional status entails increased risk of complications in relation to these diseases (León et al., 2005).

Advancing age results in changes in the body's metabolism due to organic and physiological changes that take place naturally; this makes the elderly more susceptible to food-borne illnesses (Ortega, 1992 apud Carvalho et al., 2003). This situation emphasizes the importance of the use of professional food handlers and reinforces the need for health initiatives and education programs. According to current legislation, awareness of the responsibility for the services that they provide should be a priority for managers who take care of elderly people (Rocha, 2007).

Food-borne diseases can be caused by several groups of microorganisms. Because of their diversity and pathogenesis, bacteria are the group most associated with microbial food-borne illness (Pinto, 1996).

Several factors can influence the quality of prepared meals such as the origin of the raw material and the hygiene of the utensils, the location, and the handlers involved in processing the food. Other factors, such as time and temperature, interfere directly in the natural microbial load of foods and therefore they should be controlled so that the multiplication of these microorganisms is minimized, thereby avoiding food-borne illnesses (Alves \& Ueno, 2010).
In an attempt to generate greater safety levels in food ready for consumption, the National Health Surveillance Agency (ANVISA) of the Brazilian Ministry of Health, passed Collegiate Board Resolution (RDC) No. 216/04, which established the Technical Regulation on Good Practices for Food Services, as well as RDC No. 12 of 2nd January 2001, which established microbiological sanitary standards for foods (Agência Nacional de Vigilância Sanitária, 2001, 2004).

Centers for the elderly play an important role in feeding this sector of the population from both the nutritional and social points of view. In terms of public health, it is necessary to check the quality of the meals served in these establishments in order to provide knowledge to food handlers; to minimize the risks inherent in the consumption of foods that are low in sanitary/hygienic terms; and to provide healthy, safe food for this population group (Mallon \& Bortolozo, 2004).

The aim of this study was to analyze the microbiological quality of meals served in nursing homes in the city of Ponta Grossa, Paraná before and after the training of food handlers.

\section{Materials and method}

Five nursing homes in the city of Ponta Grossa, Paraná were visited and an adapted checklist was performed, according to RDC No. 275 of 21st October, 2002 (Agência Nacional de Vigilância Sanitária, 2002). 
After the application of the checklist, and without prior notice, four samples were collected from each of the five surveyed establishments ( 1 dressing, 1 main course, 1 side dish and 1 salad), totaling 20 samples. The food was collected according to what was being served on the days of collection. The side dishes were either rice, beans or pasta. The main course was always a meat dish of the day. The other side dishes included polenta, mashed potatoes, cooked zucchini with carrots, cooked cabbage and carrots, and also cooked sweet potatoes. The salads included lettuce, carrots, cabbage, cauliflower, cucumber, tomato, chayote and beets. The samplings took place at the beginning or the middle of serving and they were collected aseptically in sterile plastic bags using the same cutlery that was used to serve the food.

Were performed microbiological analysis related to the microorganisms specified in RDC No. 12 of 2nd January 2001 (Agência Nacional de Vigilância Sanitária, 2001), which determines the count of coliforms at $45{ }^{\circ} \mathrm{C}$, Bacillus cereus, coagulase-positive staphylococci, sulphite-reducing clostridium, and detection of Salmonella sp.

The methodology used for the analyses of coliforms at $45^{\circ} \mathrm{C}$, Bacillus cereus, coagulase-positive staphylococci and sulphite-reducing clostridium, was counting by direct plating, as described by Silva et al. (2010). The classic culture method was used for the detection of Salmonella $s p$. The results were compared to the limits established by RDC No. 12/2001 to evaluate the microbiological quality of the analyzed foods (Agência Nacional de Vigilância Sanitária, 2001).

A lecture was subsequently given to the food handlers about the different types of food contamination, best practices for handling, contamination by bacteria; the results of the microbiological analysis were also presented. After the training, 20 samples were collected again, following the same pattern as the first sample collection, totaling 40 samples that were microbiologically analyzed.

The establishments were identified by numbers $1-5$ and the samples, which varied from one facility to another, did not receive a coding.

\section{Results and discussion}

\subsection{Checklist for nursing homes}

During the first visits to the nursing homes participating in this project a checklist adapted from RDC No. 275 of 21 st October, 2002 was performed. This checklist found that all the establishments had good conditions of food handling, hygiene and structure, as recommended by the legislation, with some specific issues which did not negatively affect the provision of services. It could be seen that these establishments regularly received visits in relation to health surveillance because they met the legislative standards.

Establishments Nos. 3 and 5 had separate changing rooms for each sex, while the other establishments only had one bathroom for use by their employees without direct contact with the food handling area. All the establishments had adequate conditions for hygiene and had adequate materials required for hand hygiene. Establishment No. 1 was the only one that failed to display a poster with instructions on proper hand hygiene; however, the relevant employee in that establishment had attended a course on the subject. Semprebom \& Ribeiro (2005) applied a checklist in a geriatric institution in Maringá, Paraná and found that there was only one bathroom for both sexes, what did not meet the requirements regarding general facilities for floors, doors, colors, etc., because the openings did not have protection of screens.

All the surveyed establishments promoted the cleaning of food handling facilities after meals. Establishment No. 4 kept cleaning products in the kitchen, but in a separate cabinet and without direct contact with food. Establishment No 3 stored the cleaning products in the same area where food was stored, but in different cabinets. The other locations kept cleaning products in separate areas.

Genta et al. (2005) evaluated six commercial restaurants in the city of Maringá, Paraná. In terms of the evaluation of furniture and surfaces they found no non-conformities. However, regarding items related to the hygiene of facilities, equipment and utensils, one of the restaurants had $75 \%$ non-conformities and did not meet any of the items that were considered critical to this aspect because it had not performed the disinfection stage; this establishment also used a cleaner who was not registered with the Ministry of Health and the frequency of cleaning was inadequate. Of the other five restaurants, four did not perform the disinfection stage and used cleaners who were not registered with the Ministry of Health.

Regarding the issue of pest control, all the establishments assessed in the present study reported that they were checked once a year. Establishment No. 4 reported that it was checked twice a year and establishment No. 5 reported that it was checked once a month. In all the establishments the water tanks were cleaned twice a year, except for establishment No. 5, which reported that this was performed once a month; however, no records of these activities were provided. A different scenario was found by Gama et al. (2010), who performed a checklist in accordance with RDC No. 275/2002 (Agência Nacional de Vigilância Sanitária, 2002) in 13 food and nutrition units (UANs) in hospitals in the Vale do Paraíba. They found that there was no ongoing program of integrated pest control. Vergara \& Albuquerque (2010) used RDC No. 216/2004 (Agência Nacional de Vigilância Sanitária, 2004) as a basis to evaluate five commercial restaurants in the city of Fortaleza, Ceará and they found 100\% compliance in relation to the category of water supply.

In the establishments Nos. 1, 3 and 5 waste was discarded daily, while in establishments 2 and 4 it was discarded after every meal. Garbage was collected on a daily basis in all the establishments, in accordance with the relevant legislation.

All the establishments had adequate food handling surfaces (granite and stainless steel) that were easy to clean. The refrigeration equipment was in good condition, as in the study by Genta et al. (2005), where the assessments of furniture and surfaces of the evaluated restaurants were all approved. Similarly, in the present study the kitchen utensils were appropriate and easy to clean; they were in good condition and stored in appropriate places in hygienic conditions. This was unlike the results of a study by Semprebom \& Ribeiro (2005), which reported that with respect 
to this item only about $37 \%$ of the requirements were met and that there was equipment made with permeable material such as knives with wooden handles.

With regard to the personal hygiene of the food handlers, all were using clean aprons and caps, had short nails, did not wear nail polish, and had unadorned fingers. Vergara \& Albuquerque (2010) found that issues related to the food handlers themselves were those that obtained the highest percentage of non-conformities; a different result from the present study.

In all areas surveyed in the present study storage of raw materials and ingredients was performed in appropriate locations; all materials were within their expiry date and had visible labels or markings. Products that were out-of-date or spoiled were discarded. Gama et al. (2010) reported that the main irregularities in their study were related to the storage of raw materials alongside cardboard boxes and wood.

All the establishments in the present study informed us that food handlers who were sick were replaced by another employee, and in case of wounds or skin infections they had to use bandages or gloves. Semprebom \& Ribeiro (2005) found that food handlers with skin disorders, wounds, and respiratory and gastrointestinal infections were not removed from their positions during these episodes, except in severe cases.

Based on the items from the adapted check list (40 items) the nursing homes that were evaluated showed an average level of $88 \%$ compliance with RDC No. 275/2002 in terms of physical structure, hygiene of the environment and utensils, and storage and shelf-life of food. All the establishments regularly received visits from a health surveillance professional to investigate the conditions and facilities, but only No. 3 used the services of a professional nutritionist. Semprebom \& Ribeiro (2005) emphasize the importance of a professional nutritionist to assume technical responsibility in a unit, and the establishment surveyed in their study did not have such assistance.

\subsection{Microbiological analyses - Stage 1 of sample collection}

Of the 20 samples examined in the first stage of the microbiological analysis, $75 \%$ (15 samples) were in accordance with the relevant legal standards. The results of the $25 \%$ (5 samples) which showed results above those permitted by law are shown in Table 1.
The results of the microbiological analyses of salad served at establishments Nos. 2, 3 and 4 showed the presence of coliforms at $45^{\circ} \mathrm{C}$; this denoted inadequate cleaning of this food, which is served raw and is a potential source of contamination. Furthermore, there was contamination by coliforms at $45^{\circ} \mathrm{C}$ above the levels permitted by legislation in the mashed potato served at establishment No. 3 and the pasta served at establishment No 5 . These results suggest that cross-contamination occurred through utensils which may not have been cleaned properly after use with raw foods, or due to recontamination by the food handler from, because cooked foods should be free of microorganisms. The items verified by the checklist showed no non-conformities that might explain these particular results. Campos et al. (2014) analyzed salad in 5 self- service type restaurants in the Baixada Santista area and found coliforms at $45{ }^{\circ} \mathrm{C}$ above permitted limits in only one of the restaurants.

A study by Urbano \& Souza (2011), which microbiologically evaluated food samples from a restaurant, found bacteria of fecal origin (specifically Escherichia coli) in a sample of pasta. The bacteria levels were above the level permitted by legislationw and the food was unfit for human consumption.

For Jay (2005), coliforms are important indicators of pathogens in food and water, and they can multiply in large numbers in foods under suitable conditions.

Franco \& Landgraf (2002) classify this bacteria as being of fecal origin and it is part of the intestinal flora of humans and animals. Its ingestion mainly causes diarrhoea, which may be accompanied by abdominal pain, vomiting and fever, sometimes with blood in the stools.

In addition to coliforms, coagulase-positive staphylococci and Bacillus cereus were also found in amounts above the level permitted in RDC No. 12/2001 in mashed potato served at establishment No. 3. This emphasized the existence of cross-contamination and recontamination because the checklist showed no irregularities regarding these contaminations. Bacillus cereus was also found in pasta served at establishment No. 5 , as well as coagulase-positive staphylococci in beans and pasta; however, these were within the limits permitted by law and would not cause harm to the health of consumers. Faustino et al. (2007) analyzed samples from food (including mashed potato) suspected of causing outbreaks of

Table 1. Results of the samples which were outside microbiological limits found in stage 1 of collection.

\begin{tabular}{|c|c|c|c|c|}
\hline \multirow[b]{2}{*}{ Foods } & \multirow[b]{2}{*}{$\begin{array}{l}\text { Location/Standard:RDC } \\
12 / 2001\end{array}$} & \multicolumn{3}{|c|}{ Microorganisms (CFU/g*) } \\
\hline & & Coliforms at $45^{\circ} \mathrm{C}$ & $\begin{array}{c}\text { Coagulase-positive } \\
\text { staphylococci }\end{array}$ & Bacillus cereus \\
\hline \multirow{4}{*}{ Salad } & Establishment No. 2 & $1.7 \times 10^{4}$ & $\star *$ & ** \\
\hline & Establishment No. 3 & $8.1 \times 10^{3}$ & ** & $* *$ \\
\hline & Establishment No. 4 & $4.7 \times 10^{3}$ & ** & $* *$ \\
\hline & Standard: RDC 12/2001 & $10^{2}$ & $* *$ & $* *$ \\
\hline \multirow{2}{*}{ Mashed potato } & Establishment No.3 & $7 \times 10$ & $1.6 \times 10^{5}$ & $2.2 \times 10^{5}$ \\
\hline & Standard: RDC 12/2001 & $5 \times 10$ & $10^{3}$ & $10^{3}$ \\
\hline \multirow{2}{*}{ Pasta } & Establishment No. 5 & $4.4 \times 10^{3}$ & $4 \times 10^{2}$ & $10^{2}$ \\
\hline & Standard: RDC 12/2001 & $10^{2}$ & $10^{3}$ & $10^{3}$ \\
\hline
\end{tabular}

* CFU/g: colony forming unit per gram. ${ }^{* *}$ Analyses not required by RDC No. 12 of 2nd January 2001 (Agência Nacional de Vigilância Sanitária, 2001). 
food poisoning in the Baixada Santista area, but and found no contamination by bacteria.

Vasconcelos \& Carvalho (2010) evaluated the microbiological profile of 241 samples from food from restaurants in the city of Camaçari, Bahia and $38 \%$ were found to be unfit for consumption. Of the total of contaminated samples, $56 \%$ were foods derived from flour, cereals, grains etc, and $9 \%$ were derived from cooked roots and tubers; Bacillus cereus (21\%) and coagulase-positive staphylococci (4\%) were among the contaminated samples.

Urbano \& Souza (2011) found levels of Staphylococcus aureus above the legally permitted levels in samples of pasta that had been stored for a few days. The authors state that Staphylococcus aureus forms part of the normal flora of the mucous membranes and skin and it can easily contaminate food by producing toxins which, if ingested, can cause food poisoning. A study conducted by Piacentini \& Silva (2014) concluded that food handlers can cause contamination of food through direct contact with it, thus causing staphylococcal intoxication.

Jay (2005) observes that the microorganisms which cause diseases can be transmitted by contaminated feces, as well as through the hands of food handlers, insects and water. In relation to staphylococci, the same author reported that most of these bacteria are found near mucosal and skin surfaces, such as the nostrils, armpits and groin; the nostrils, hands and arms of food handlers are the most important sources of food contamination.

Hobbs \& Roberts (1998) state that bacteria such as Bacillus cereus produce spores which can survive the cooking process and subsequently produce bacilli, which produce toxins in foods that have already been cooked when stored at favorable temperatures. Angeloff et al. (2014) conducted microbiological analyses of mashed potato served in a university hospital in the city of Rio de Janeiro; although several samples were unsuitable due to the presence of other bacteria, contamination by Bacillus cereus and coagulase-positive staphylococci were not found.

\subsection{Training of food handlers}

After the microbiological analyses were performed, lectures were given to the food handlers working in the surveyed establishments in order to clarify the different types of food contamination and to reinforce appropriate practices for hygiene in relation to hands, utensils, environment and food. The food handlers were given information about the analyzed microorganisms and the diseases caused by the ingestion of these bacteria or their toxins; they were also presented with the results of the microbiological analysis of the establishment in which they worked. The food handlers showed interest in the subject and stated that intended to improve the practices that had been shown to be at fault. This was similar to what occurred in a study by Senter et al. (2013), where 186 employees working in the food industry in the state of Santa Catarina declared that they were interested in learning about (and putting into practice) the issues discussed above, including the microbiology of food; hygiene related to individuals, facilities and equipment; food-borne diseases; pest control and food storage.

According to Campos \& Ueno (2014), after the training of food handlers working in 3 bakeries in Ubatuba, São Paulo, significant changes were observed in their work routine and in relation to hygiene related to individuals, food, utensils and equipment.

\subsection{Microbiological analyses - Stage 2 of sample collection}

The results of the second stage of the microbiological analyses of the 20 samples are shown in Table 2 . It can be seen that 2 samples (10\%) showed evidence of contamination; these were from Establishments 2 and 3.

Table 2 shows that there was the presence of Salmonella sp. in the salad sample from establishment No. 2, classifying this food as unfit for human consumption. This contamination may have occurred from the ground, from the hands of the food handlers, or through cross-contamination and it was in evidence due to poor hygiene control of this food. This bacterium is widely distributed in nature, and humans and animals are its main hosts (Franco \& Landgraf, 2002). According to Jay (2005), the ingestion of Salmonella sp. can cause symptoms such as nausea, vomiting, abdominal pain, headache, chills, diarrhoea, weakness, muscle fatigue, fever, nervousness, and drowsiness.

A study by Coelho et al. (2007) observed the occurrence of Salmonella sp. in $6.7 \%$ of samples of lettuce grown in the soil; this differed from samples grown hydroponically, which showed no evidence of Salmonella sp. The samples were collected from three supermarket chains in the city of Cuiabá, Mato Grosso.

In the present study, coliforms at $45^{\circ} \mathrm{C}$ were found in the sample of salad from establishment No. 3 at levels above the permitted standard. In establishments Nos. 4 and 5 there was also the presence of coliforms at $45^{\circ} \mathrm{C}$ but within the levels permitted by RDC No. 12/2001. This highlights the need for proper hygiene and the use of sanitizers to disinfect food, which was passed on to the food handlers in their training.

Table 2. Results of the samples which were outside microbiological limits found in stage 2 of collection.

\begin{tabular}{|c|c|c|c|}
\hline \multirow[b]{2}{*}{ Food } & \multirow[b]{2}{*}{$\begin{array}{c}\text { Location/ } \\
\text { Standard: RDC 12/2001 }\end{array}$} & \multicolumn{2}{|c|}{ Microorganisms } \\
\hline & & Salmonella sp. & $\begin{array}{c}\text { Coliforms at } 45^{\circ} \mathrm{C} \\
\left(\mathrm{CFU} / \mathrm{g}^{*}\right)\end{array}$ \\
\hline \multirow{2}{*}{ Salad } & Establishment No. 2 & Presence in $25 \mathrm{~g}$ & $<10$ \\
\hline & Standard: RDC 12/2001 & Absence in $25 \mathrm{~g}$ & $10^{2}$ \\
\hline
\end{tabular}

* CFU/g: colony forming unit per gram. 


\section{Conclusion}

The use of the checklist showed that the nursing homes met the requirements of the legislation and there was regular supervision by a professional health surveillance service. However, of the total number of samples that were analyzed (40 samples), $17.5 \%$ (7 samples) were unfit for consumption and within that percentage $15 \%$ (6 samples) were coliforms at $45^{\circ} \mathrm{C}, 2.5 \%$ (1 sample) were coagulase-positive staphylococci, $2.5 \%$ (1 sample) were Bacillus cereus and 2.5\% (1 sample) were Salmonella sp.

This study shows that the main contaminating factors were the food handlers, cross-contamination, and inadequate hygiene in relation to raw salads. This study also shows the importance of training for these professionals and the importance of controlling the quality of food served to this age group.

\section{References}

Agência Nacional de Vigilância Sanitária - ANVISA. (2001, January 10). Regulamento técnico sobre padrões microbiológicos para alimentos (Resolução de Diretoria Colegiada - RDC no 12, de 02 de janeiro de 2001). Diário Oficial da União. Retrieved from http:// portal.anvisa.gov.br/wps/wcm/connect/a47bab8047458b909541d5 3fbc4c6735/RDC_12_2001.pdf?MOD=AJPERES

Agência Nacional de Vigilância Sanitária - ANVISA. (2002, October 23). Regulamento técnico de procedimentos operacionais padronizados aplicados aos estabelecimentos produtores/industrializadores de alimentos e a lista de verificação das boas práticas de fabricação em estabelecimentos produtores/industrializadores de alimentos (Resolução da Diretoria Colegiada no 275 de 21 de outubro de 2002). Diário Oficial da União. Retrieved from http://portal.anvisa. gov.br/wps/wcm/connect/dcf7a900474576fa84cfd43fbc4c6735/ $\mathrm{RDC}+\mathrm{N} \% \mathrm{C} 2 \% \mathrm{BA}+275,+\mathrm{DE}+21+\mathrm{DE}+\mathrm{OUTUBRO}+\mathrm{DE}+2002$. pdf?MOD=AJPERES

Agência Nacional de Vigilância Sanitária - ANVISA. (2004, September 16). Regulamento técnico de boas práticas para serviços de alimentação (Resolução de Diretoria Colegiada nº 216, de 15 de setembro de 2004). Diário Oficial da União. Retrieved from http:// portal.anvisa.gov.br/wps/wcm/connect/4a3b680040bf8cdd8e5dbf 1b0133649b/RESOLU\%C3\%87\%C3\%83O-RDC+N+216+DE+15 $+\mathrm{DE}+$ SETEMBRO+DE+2004.pdf?MOD=AJPERES

Alves, M. G., \& Ueno, M. (2010). Restaurantes self-service: segurança e qualidade sanitária dos alimentos servidos. Revista de Nutrição, 23(4), 573-580. http://dx.doi.org/10.1590/S1415-52732010000400008.

Angeloff, M., Braz, M. M., Silva, S. F., Santos, E. F. A. S., Matos, J. G. C. N., Sono, P. A. J. M. R., \& Queiroz, M. L. P. (2014). Avaliação microbiológica da preparação purê de batata destinada à pacientes internados em um hospital universitário na cidade do Rio de Janeiro e susceptibilidade aos antimicrobianos em cepas de enterobactérias isoladas da dieta. In Anais do $12^{\circ}$ Congresso Latino Americano de Microbiologia e Higiene de Alimentos (Vol. 1, No. 1), Foz do Iguaçu, Paraná, Brasil. São Paulo: Blucher.

Campos, C. C. N., Losano, V. F., Gouvinhas, M. P., \& Simas, K. N. (2014). Avaliação microbiológica de saladas cruas e utensílios, em restaurantes self service da baixada santista. Revista Higiene Alimentar, 28(230-231), 79-84.

Campos, E. G., \& Ueno, M. (2014). Importância do treinamento para manipuladores de alimentos, em panificadores. Revista Higiene Alimentar, 28(230-231), 61-66.

Carvalho, E. N., Silva, F. R., Melo, M. T. S. M., \& Carvalho, C. M. R. G. (2003). Avaliação da qualidade nutricional das refeições servidas aos idosos em instituição asilar. Estudos Interdisciplinares sobre o Envelhecimento, 5, 119-136.

Coelho, E. M., Rosa, O. O., \& Lima, M. G. (2007). Avaliação da qualidade microbiológica de alface (Lactuca Sativa L.) em plantio direto e hidropônico. Revista Higiene Alimentar, 21(149), 94-98.

Faustino, J. S., Passos, E. C., Mello, A. R. P., Araújo, A. L. M., Souza, C. V., Jorge, L. I. F., \& Zamarioli, L. A. (2007). Análises microbiológicas de alimentos processados na Baixada Santista, envolvidos em doenças transmitidas por alimentos, no período de 2000-2006. Revista do Instituto Adolfo Lutz, 66(1), 26-30. Retrieved from http://periodicos. ses.sp.bvs.br/pdf/rial/v66n1/v66n1a04.pdf

Franco, B. D. G. M., \& Landgraf, M. (2002). Microbiologia dos alimentos. São Paulo: Atheneu.

Gama, C. A., Silva, C. J., \& Ueno, M. (2010). Unidades de alimentação e nutrição hospitalares em cidades do Vale do Paraíba: avaliação das condições estruturais e higiênico-sanitárias. Revista Higiene Alimentar, 25(192-193), 35-41.

Genta, T. M. S., Maurício, A. A., \& Matioli, G. (2005). Avaliação das boas práticas através de check-list aplicado em restaurantes self-service da região central de Maringá, Estado do Paraná. Acta Scientiarum: Health Science, 27(2), 151-156.

Hobbs, B. C., \& Roberts, D. (1998). Toxinfecções e controle higiênicosanitário de alimentos. São Paulo: Livraria Varela.

Jay, J. M. (2005). Microbiologia de alimentos (6th ed.). Porto Alegre: Artmed.

León, L. M., Corrêa, A. M. S., Panigassi, G., Maranha, L. K., Sampaio, M. F. A., \& Escamilla, R. P. (2005). A percepção de insegurança alimentar em famílias com idosos em Campinas, São Paulo, Brasil. Cadernos de Saúde Pública, 21(5), 1433-1440. http://dx.doi.org/10.1590/ S0102-311X2005000500016. PMid:16158149.

Mallon, C., \& Bortolozo, E. A. F. Q. (2004). Alimentos comercializados por ambulantes: uma questão de segurança alimentar. Publicatio UEPG: Ciências Biológicas e da Saúde, 10(3-4), 65-76.

Piacentini, K. C., \& Silva, A. P. F. (2014). Ocorrência de Staphylococcus aureus coagulase positivo em mãos de manipuladores de alimentos de uma unidade de alimentação e nutrição. Revista Higiene Alimentar, 28(230-231), 52-55.

Pinto, A. F. M. A. (1996). Doenças de origem microbiana transmitidas pelos alimentos. Millenium, 4, 91-100.

Rocha, A. (2007). Particularidades dos serviços de alimentação em instituições geriátricas, alimentação humana. Revista da Sociedade Portuguesa de Ciências da Nutrição e Alimentação, 13(1), 3-9.

Semprebom, K. A., \& Ribeiro, C. S. G. (2005). Análise da estrutura física, operacional e organizacional de uma Unidade de Alimentação e Nutrição de uma Instituição Geriátrica, Maringá, PR. Nutrire, 30, 53-65.

Senter, L., Michielin, E. M. Z., \& Vieira, M. A. (2013). Treinamentos em higiene e boas práticas a colaboradores de serviços de alimentação, em três municípios do oeste de Santa Catarina. Revista Higiene Alimentar, 27(222-223), 47-50.

Silva, N., Junqueira, V. C. A., Silveira, N., Taniwaki, M., Santos, R., \& Gomes, R. (2010). Métodos de análise microbiológica de alimentos (4th ed). São Paulo: Livraria Varella.

Urbano, G. R., \& Souza, G. C. (2011). Qualidade microbiológica de alimentos prontos e sua relação com as doenças transmitidas por alimentos. Revista Higiene Alimentar, 25(200-201), 58-61.

Vasconcelos, A. C., \& Carvalho, C. D. Fo. (2010). Perfil microbiológico das refeições servidas em restaurantes do município de Camaçari, BA. Revista Higiene Alimentar, 25(192-193), 77-81.

Vergara, C. M. A. C., \& Albuquerque, M. B. (2010). Condições higiênicosanitárias de restaurantes comerciais da cidade de Fortaleza, CE. Revista Higiene Alimentar, 25(192-193), 29-34. 